Article

\title{
Inactivation of Aeromonas hydrophila and Vibrio parahaemolyticus by Curcumin-Mediated Photosensitization and Nanobubble-Ultrasonication Approaches
}

\author{
Shamil Rafeeq ${ }^{1}$, Setareh Shiroodi ${ }^{1}$, Michael H. Schwarz ${ }^{1,2}$, Nitin Nitin ${ }^{3,4}$ and \\ Reza Ovissipour 1,2,5,* \\ 1 Virginia Seafood Agricultural Research and Extension Center, Virginia Tech, Hampton, VA 23669, USA; \\ shamilrafeeq363@gmail.com (S.R.); shiroodi@vt.edu (S.S.); mschwarz@vt.edu (M.H.S.) \\ Center for Coastal Studies (Coastal@VT), Virginia Tech, Blacksburg, VA 24061, USA \\ 3 Department of Food Science and Technology, University of California-Davis, Davis, CA 95616, USA; \\ nnitin@ucdavis.edu \\ 4 Department of Agricultural and Biological Engineering, University of California-Davis, \\ Davis, CA 95616, USA \\ 5 Department of Food Science and Technology, Virginia Tech, Blacksburg, VA 24060, USA \\ * Correspondence: ovissi@vt.edu
}

Received: 20 July 2020; Accepted: 14 September 2020; Published: 16 September 2020

\begin{abstract}
The antimicrobial efficacy of novel photodynamic inactivation and nanobubble technologies was evaluated against Vibrio parahaemolyticus and Aeromonas hydrophila as two important aquatic microbial pathogens. Photodynamic inactivation results showed that LED $(470 \mathrm{~nm})$ and UV-A (400 nm)-activated curcumin caused a complete reduction in $V$. parahaemolyticus at 4 and $22{ }^{\circ} \mathrm{C}$, and a greater than $2 \log \mathrm{cfu} / \mathrm{mL}$ reduction in $A$. hydrophila, which was curcumin concentration-dependent $(p<0.05)$. Furthermore, the photodynamic approach caused a greater than $6 \log \mathrm{cfu} / \mathrm{mL} V$. parahaemolyticus reduction and more than $4 \log \mathrm{cfu} / \mathrm{mL}$ of $A$. hydrophila reduction in aquaponic water samples $(p<0.05)$. Our results with the nanobubble technology showed that the nanobubbles alone did not significantly reduce bacteria $(p>0.05)$. However, a greater than $6 \log \mathrm{cfu} / \mathrm{mL}$ A. hydrophila reduction and a greater than $3 \log \mathrm{cfu} / \mathrm{mL}$ of $V$. parahaemolyticus reduction were achieved when nanobubble technology was combined with ultrasound $(p<0.05)$. The findings described in this study illustrate the potential of applying photodynamic inactivation and nanobubble-ultrasound antimicrobial approaches as alternative novel methods for inactivating fish and shellfish pathogens.
\end{abstract}

Keywords: curcumin; LED; UV-A; nanobubbles; aquatic pathogens; aquaponics

\section{Introduction}

Fisheries and aquaculture are a growing industry, and seafood consumption has been increased from an average of $9.9 \mathrm{~kg}$ per capita in the 1960s, to $20.3 \mathrm{~kg}$ per capita in 2017 [1]. Pathogenic Vibrio spp., specifically, Vibrio parahaemolyticus, are the leading causes of seafood-associated disease in U.S., and $45 \%$ of the seafood-borne outbreaks are related to molluscan shellfish [2]. Vibrio spp. are natural inhabitants of estuaries and coastal marine environments. They can be found in water, sediments, and all flora and fauna in coastal environments, including freshly harvested seafood. Another aquatic important microorganism is Aeromonas hydrophila which can cause disease in both fish and humans, affecting seafood safety, quality, and causing severe losses for production and marketing [3]. The importance of controlling these pathogenic bacteria is highlighted by the fact that the aquaponics industry is 
growing globally, and the number of aquaponics producers in the U.S. has continued to grow [4]. Since most fresh produce is consumed raw, the potential for cross-contamination and transfer of pathogenic bacteria from aquaculture water to edible parts of the plants represents a serious risk to public health [5]. Controlling zoonotic fish diseases and foodborne pathogens in recirculating aquaculture systems and aquaponics using antibiotics, chemical sanitizers, and pesticides, is challenging due to the sensitivity of the microbial community in biofilters which oxidize ammonia to nontoxic nitrate, chemical residue concerns in both fish and plants, and regulatory stand points. These challenges motivated researchers to develop novel chemical-free, or bio-based antimicrobial approaches. For example, the application of light-based interventions has emerged recently as an alternative approach to inactivate bacteria [6-8]. The photosensitizer curcumin, in combination with light, has been used for inactivation of various pathogenic and spoilage microorganisms [7-12]. Exposure of curcumin to light radiation results in photooxidative generation of reactive oxygen species (ROS), which have strong antimicrobial properties [7,8]. Recent reports have documented curcumin-mediated photooxidative DNA damage as a mechanism for bacterial inactivation $[7,8,13]$. Light emitting diodes (LED) and UV-A are two main safe sources of lights for photodynamic inactivation which have been used to improve sanitation of food products $[7,8,14]$.

Nanobubble technology represents another promising antimicrobial approach that has been recently described. Cavitative collapse of nanobubbles generates reactive oxygen species, as well as a physical insult to microbial cell structures [15-18]. Due to nanobubbles' unique properties, this technology has been applied in various areas of advanced science and technology including engineering, medical, agricultural, and food sectors [16-21]; for cleaning surfaces [22-24]; dental hygiene [25]; wound cleaning [16,17]; removing bacteria from fresh produce [26]; inactivation of norovirus [27]; and removing microbial biofilms [21]. Nanobubbles can exist in both bulk solution and at liquid-solid interfaces, and due to their unique physical properties (nanosize diameter, negative surface charge and Brownian motion), nanobubbles can remain stable for up to $24 \mathrm{~h}$, resulting in a supersaturated bubble phase [15]. However, only a few studies have investigated the antimicrobial properties of nanobubbles alone or in combination with chemicals and other nonthermal processes such as ultrasound $[21,26,27]$. Thus, to address the potential challenges in water sanitation in Recirculating Aquaculture Systems (RAS) and aquaponics, we propose the use of two technologies including curcumin-mediated photosensitization and nanobubbles with ultrasound to inactivate $V$. parahaemolyticus and A. hydrophila. The efficacy of light (LED and UV-A)-activated curcumin at different concentrations and exposure time and temperature against these bacteria was evaluated. Antimicrobial properties of synergistic approaches of nanobubbles-ultrasound were also determined at different exposure times at room temperature.

This study illustrates the potential of light activated food grade antimicrobial materials, such as curcumin, and a novel chemical-free approach combining nanobubbles and ultrasound for water sanitation in intensive RAS and aquaponics systems to reduce reliance on chemical-based approaches.

\section{Materials and Methods}

\subsection{Bacterial Strains and Inoculum Preparation}

Clinically isolated A. hydrophila was provided by David Crosby from Virginia State University, and V. parahaemolyticus, was isolated from sea water. Frozen stock cultures of the strains were streaked on agar media and incubated at 35 and $37^{\circ} \mathrm{C}$ for $24 \mathrm{~h}$, for $V$. parahaemolyticus and A. hydrophila, respectively. A loop of these cultures was transferred two successive times into $10 \mathrm{~mL}$ tryptic soy broth and incubated at 37 and $35^{\circ} \mathrm{C}$ (V. parahaemolyticus) for $18 \mathrm{~h}$. A total of $1 \mathrm{~mL}$ of the broth culture was pipetted into a $1.5 \mathrm{~mL}$ centrifuge tube and centrifuged at $10,483 \times g$ for $2 \mathrm{~min}$. Supernatant was discarded, and the resultant the pelleted cells were resuspended with $1 \mathrm{~mL}$ sterile phosphate buffer saline (PBS), and centrifuged at 10,483 $\times g$ for $2 \mathrm{~min}$. This process was repeated twice, and the pellet 
from the second wash was resuspended in $1 \mathrm{~mL}$ sterile PBS. The population of bacteria in inoculum was approximately $10^{9} \mathrm{CFU} / \mathrm{mL}$.

\subsection{Preparation of Curcumin Solutions}

Different final concentrations of curcumin $(2,10$, and $20 \mathrm{mg} / \mathrm{L})$ were prepared by diluting the $20 \mathrm{mM}$ stock solution of curcumin with deionized water. Stock solution was prepared by dissolving $737 \mathrm{mg}$ curcumin in $100 \mathrm{~mL}$ of $99 \%$ ethanol according to Oliveira et al. [7,8]. These concentrations were selected based our preliminary results and according to Oliveira et al. $[7,8]$.

\subsection{Light Irradiation of Bacteria}

Two light sources were used in this study including UV-A (320-400 nm; 18W; Actinic BL, Philips, Holland) and light-emitting diode (LED) arrays (470 nm; energy density of $3.6 \mathrm{~J} / \mathrm{cm}^{2}$, AquaBasik, Yescom USA, Inc., City of Industry, CA, USA).

The efficacy of curcumin activated by UV-A and LED lights was studied against $V$. parahaemolyticus and A. hydrophila. Samples with curcumin were prepared by adding $5 \mathrm{~mL}$ fresh V. parahaemolyticus and A. hydrophila cell suspensions to $5 \mathrm{~mL}$ curcumin solution $(2,10$, and $20 \mathrm{mg} / \mathrm{L})$. The final concentration of the cells was $10^{6} \mathrm{cfu} / \mathrm{mL}$. Samples were placed into sterile 6-well clear polystyrene microplates and were treated by UV-A for 5 and $15 \mathrm{~min}$, and LED for 15 and $30 \mathrm{~min}$ (based on our preliminary data, no bacterial reduction was observed within $15 \mathrm{~min}$ exposure to LED) at 4 and $22^{\circ} \mathrm{C}$. After exposure, $V$. parahaemolyticus and A. hydrophila were cultured on TCBS (Thiosulfate Citrate Bile Salts Sucrose) and TSA (Tryptic Soy Agar), and incubated at 35 and $37^{\circ} \mathrm{C}$ for $48 \mathrm{~h}$, respectively. Bacteria with curcumin without exposure to lights, and bacteria without curcumin exposed to lights were used as control groups. All the experiments were repeated at least two times in triplicate $(n=6)$. The $\mathrm{pH}$ of the water samples was adjusted to 5.6 using $1 \mathrm{~N}$ citric acid.

\subsection{Photodynamic Inactivation in RAS-Aquaponics Water}

RAS-aquaponics water sanitation was simulated using water from a seventy liter pilot-scale RAS-aquaponics system (tilapia-pepper, Built by Virginia Seafood AREC). Before conducting the experiment, to ensure that there were no Vibrio sp. and Aeromonas in the RAS-aquaponics water, $100 \mathrm{~mL}$ RAS water was filtered using $0.45 \mu \mathrm{m}$, and a filter was placed on TCBS and selective Aeromonas medium (RYAN) (CM0833, Oxoid Ltd, Basingstoke, UK), and no bacterial colonies were observed. The $\mathrm{pH}$ of the water samples was adjusted to 5.6 using $1 \mathrm{~N}$ citric acid. Then, samples were prepared as mentioned previously, by mixing $5 \mathrm{~mL}$ of the $\mathrm{pH}$-adjusted aquaponics water with bacterial cell suspensions to obtain $10^{6} \mathrm{cfu} / \mathrm{mL}$ and $10 \mathrm{mg} / \mathrm{L}$ curcumin concentrations, which were treated with light sources for 5,10 , and $20 \mathrm{~min}$.

\subsection{Nanobubble Inactivation of Bacteria}

The synergistic antimicrobial activity of nanobubbles and ultrasound was studied against V. parahaemolyticus and A. hydrophila. A nanobubble solution was provided using deionized water and pure oxygen gas using a Moleaer $25 \mathrm{~L}$ nanobubble generator (Moleaer Inc., Torrance, CA, USA). Our preliminary experiments showed that nanobubbles produced by pure oxygen showed stronger antibiofilm and antimicrobial properties as compared to nanobubbles generated by pure carbon dioxide or air. A total of $1 \mathrm{~mL}$ of the previously washed bacterial cell suspensions was added to $9 \mathrm{~mL}$ deionized water containing nanobubbles. The solutions were exposed to ultrasound for 5, 10, and $15 \mathrm{~min}$. Bacteria in PBS with ultrasound and bacteria in nanobubbles without ultrasound were used as control.

\subsection{Data Analysis}

Each experiment was conducted a minimum of three times to ensure reproducibility. The results were expressed as the mean of the replicates \pm standard deviation. The significance of differences 
among the biofilm removal treatments was determined using one-way analysis of variance (ANOVA), and differences were considered significant at $p<0.05$. The normality of the data was determined using one sample Kolmogorov-Smirnov test using JMP ${ }^{\circledR}$ Pro 15.0.0 (SAS Institute Inc., Cary, NC, USA).

\section{Results and Discussion}

\subsection{Photodynamic Bacterial Inactivation}

\subsubsection{Impact of Curcumin Concentration and Light Wavelength}

Figure 1 illustrates the impact of light (UV-A) in combination with curcumin at various concentrations on $V$. parahaemolyticus and A. hydrophila inactivation within 15 min with the limit of detection below $0.5 \log \mathrm{cfu} / \mathrm{mL}\left({ }^{*}\right)$. UV-A activated curcumin with concentrations of 1,5 , and $10 \mathrm{mg} / \mathrm{L}$ reduced from 2 to $5 \mathrm{log} \mathrm{cfu} / \mathrm{mL}$ of $V$. parahaemolyticus, and from 1 to $4.5 \log \mathrm{cfu} / \mathrm{mL}$ of A. hydrophila, indicating that UV-A activated curcumin at low concentrations has strong antimicrobial properties, and by increasing the curcumin concentration from 1 to $10 \mathrm{mg} / \mathrm{L}$, the antimicrobial activity increased significantly. Additional controls including bacteria with curcumin and no light and bacteria without curcumin and light, with no reduction, were applied (data not shown).
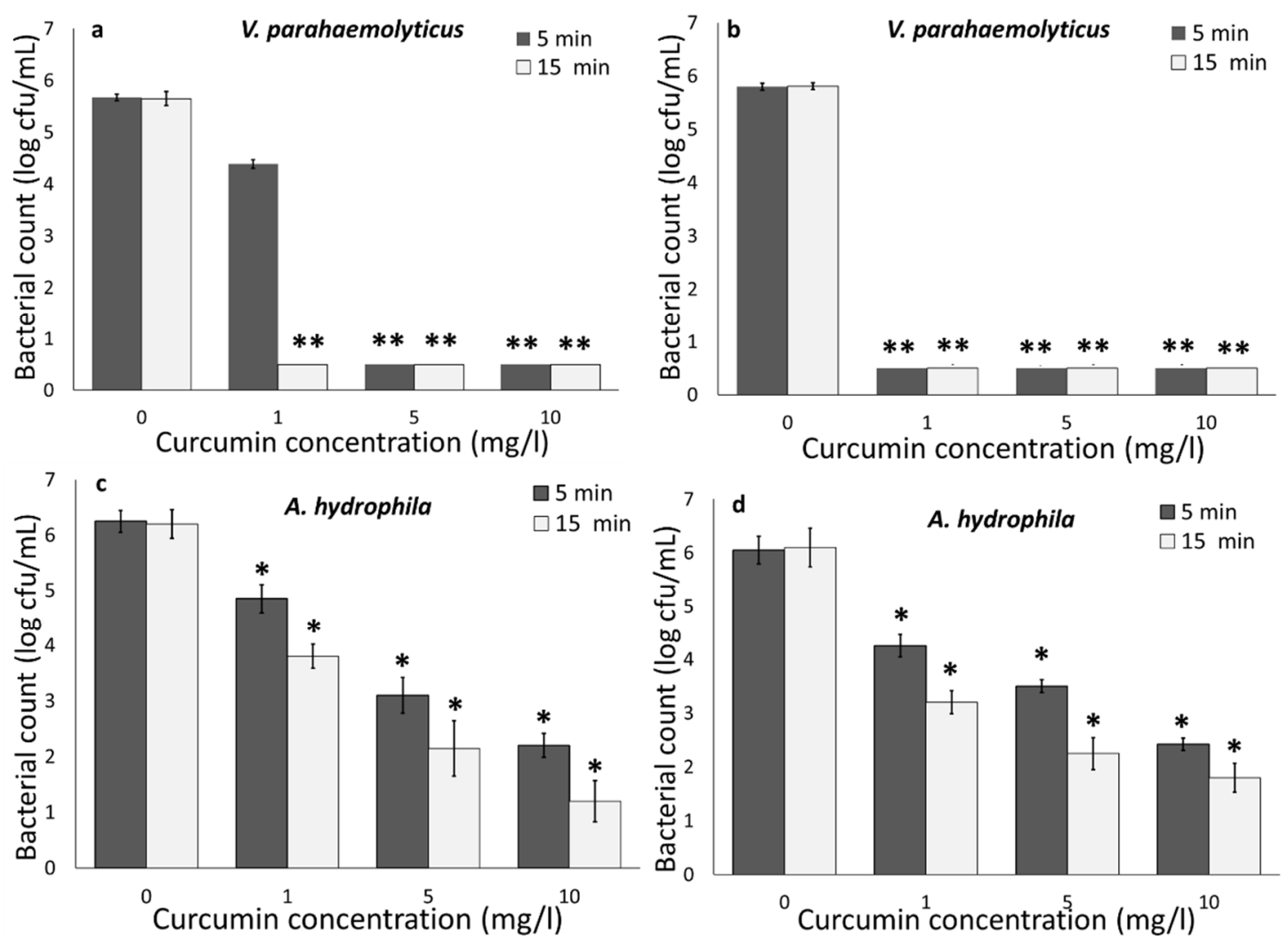

Figure 1. Effect of curcumin concentrations on the inactivation of $V$. parahaemolyticus at (a) 22 and (b) $4{ }^{\circ} \mathrm{C}$, and A. hydrophila at (c) 22 and (d) $4{ }^{\circ} \mathrm{C}$, using UV-A and curcumin. Statistical difference was determined based on $p<0.05\left(^{*}\right)$. Samples with two asterisks $\left(^{* *}\right)$ were below the limit of detection $(0.5 \log \mathrm{cfu} / \mathrm{mL})$.

Bacteria were also exposed to LED light $(470 \mathrm{~nm})$ for 15 and $30 \mathrm{~min}$ with curcumin (our preliminary experiments showed no significant reduction within $10 \mathrm{~min}$ exposure). The results indicated that increasing the curcumin concentration from 1 to $10 \mathrm{mg} / \mathrm{L}$ resulted in increasing the efficacy of the combination approach to inactivate bacteria. Curcumin concentration demonstrated a strong impact on the reduction in V. parahaemolyticus and A. hydrophila regardless of the light source. Similar results 
were previously reported by other researchers. Oliveira et al. [7] reported an increase in the inactivation of Listeria innocua and E. coli O157:H7 by increasing curcumin concentrations and activating by UV-A, and Wu et al. [12] demonstrated an increase in $V$. parahaemolyticus inactivation by increasing curcumin concentrations (5 to $20 \mu \mathrm{M}$ ) and LED.

Overall, the results indicated that $V$. parahaemolyticus was less resistant to light-activated curcumin compared to $A$. hydrophila. A higher reduction was also observed for $V$. harveyi compared to A. salmonicida [28], and V. parahaemolyticus exhibited a faster rate of inactivation compared to Staphylococcus aureus and Lactobacillus plantarum in the presence of 405 as well as $470 \mathrm{~nm}$ LED illumination [29]. Gram-negative bacteria (E. coli O157:H7) are more resistant to light-activated curcumin, compared to Gram-positive bacteria (L. innocua) [7]), which is mainly because of the Gram-positive bacteria outer wall structure permeability for curcumin [30]. The outer-wall structure of Gram-positive bacteria contains up to 100 peptidoglycan layers, which display a relatively high degree of porosity, which is permeable to molecules such as curcumin [30]. However, on the contrary, a higher sensitivity of Gram-negative bacteria compared to Gram-positive bacteria has also been reported [29,31]. Furthermore, our results indicated that UV-A $400 \mathrm{~nm}$ caused a higher bacterial reduction compared to LED $470 \mathrm{~nm}$. After $5 \mathrm{~min}$ of light treatment, a greater than $5 \log \mathrm{cfu} / \mathrm{mL}$ of $V$. parahaemolyticus and a greater than $4 \log \mathrm{cfu} / \mathrm{mL}$ reduction in A. hydrophila were achieved by UV-A light. However, LED $470 \mathrm{~nm}$ only reduced 3 and $3.5 \mathrm{log} \mathrm{cfu} / \mathrm{mL}$ of $V$. parahaemolyticus and A. hydrophila, respectively. Similar results have been previously observed by other researchers, where at an equal radiant energy dosage of $1100 \mathrm{~J} / \mathrm{cm}^{2}$, the $395 \mathrm{~nm}$ LED treatment was more effective with a $2.48 \mathrm{log}$ $\mathrm{cfu} / \mathrm{g}$ reduction, than the $455 \mathrm{~nm}$ with a $1.6 \mathrm{log} \mathrm{cfu} / \mathrm{g}$ reduction in Salmonella in wheat flour [14]. Kumar et al. [29] also reported low antimicrobial properties of $460 \mathrm{~nm}$ compared to $405 \mathrm{~nm}$, regardless of bacterial species and illumination temperature. This can be explained by the fact that UV-A (400 nm) can generate ROS and directly cause microbial cell damage compared to visible light [29], and UV-A light may excite curcumin molecules compared to LED $470 \mathrm{~nm}$ [7]. UV-A has been used to activate curcumin for treating E. coli and L. innocua in water and fresh produce [7,8]. Moreover, mainly LED or visible light were used in combination with photosensitizers for inactivating bacteria including Vibrio sp. and Aeromonas sp. [12,28,29,32,33].

The results of these experiments illustrate the potential of using the photodynamic inactivation approach for food production systems for which using antibiotics, therapeutics, and pesticides is restricted such as intensive indoor aquaculture systems, aquaponics, and the oyster industry.

\subsubsection{Impact of Temperature}

Similar to the room temperature $\left(22^{\circ} \mathrm{C}\right)$ experiment, curcumin and UV-A light together caused a more than $5 \log \mathrm{cfu} / \mathrm{mL}$ reduction in $V$. parahaemolyticus and a more than $4 \log \mathrm{cfu} / \mathrm{mL}$ reduction in $A$. hydrophila at $4{ }^{\circ} \mathrm{C}$ (Figure 1a-d). Compared to UV-A treatment, LED $470 \mathrm{~nm}$ only caused a 4.5 and $2.5 \log \mathrm{cfu} / \mathrm{mL}$ reduction in V. parahaemolyticus and A. hydrophila, respectively at $4{ }^{\circ} \mathrm{C}$ (Figure 2a-d). Temperature control is a critical food safety and quality step during seafood harvesting (particularly oysters) and processing. It has been reported that antimicrobial properties of UV-A light-activated bio-based compounds (e.g., gallic acid and lactic acid) were inhibited at refrigerated temperatures against E. coli O157:H7 and L. innocua [6-8], which is due to the lower bacterial metabolism rates at a lower temperature. Other studies also indicated that bacterial inactivation in the presence of antimicrobial compounds increases with increasing temperature [29] due to the higher metabolism rate and cellular activity $[7,8,29]$. Due to the higher degree of cellular activity and thus more metabolic burden at a higher temperature, bacteria are more susceptible to antimicrobial agents. Several possible reasons could be attributed to the ability of light-activated curcumin at $4{ }^{\circ} \mathrm{C}$ to inactivate bacteria, including: light activation of curcumin is independent from bacterial metabolism [7]; increased proportion of unsaturated fatty acids in bacterial membrane at lower temperatures [29,31]; entering some bacterial species such as $V$. parahaemolyticus to a viable but not culturable (VBNC) state at lower temperatures [29]. Thus, the antimicrobial properties of light-activated curcumin at refrigerated 
temperatures indicate that photodynamic inactivation using curcumin could be a promising approach for sanitizing seafood, live organisms (shellfish), and water to maximize the bacterial inactivation and shelf life of the products.
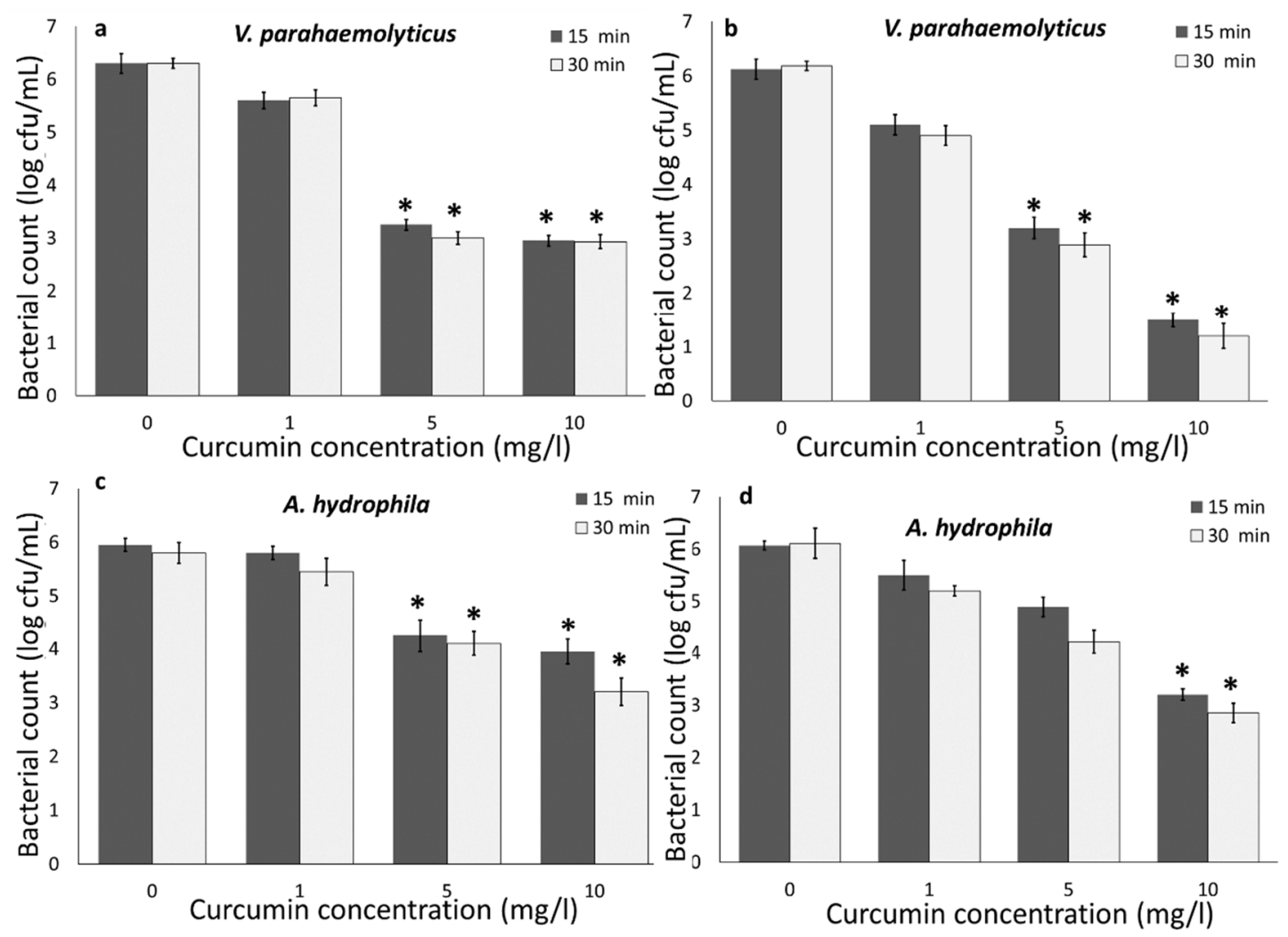

Figure 2. Effect of curcumin concentrations on the inactivation of V. parahaemolyticus at (a) 22 and (b) $4{ }^{\circ} \mathrm{C}$, and A. hydrophila at (c) 22 and (d) $4{ }^{\circ} \mathrm{C}$, using LED and curcumin. Statistical difference was determined based on $p<0.05\left(^{*}\right)$.

\subsubsection{Bacterial Inactivation in RAS-Aquaponics Water}

The antibacterial properties of curcumin activated by UV-A light against V. parahaemolyticus and A. hydrophila was evaluated in aquaponics water with $6 \mathrm{mg} / \mathrm{L}$ total suspended solid (TSS) to best mimic the application of this approach in the aquaculture or aquaponics industry. Figure 3 shows the bactericidal properties of the combination of curcumin and UV-A light against V. parahaemolyticus and A. hydrophila within 20 min exposure. As represented in Figure 3a, TSS reduced the efficacy of the UV-A and curcumin combination. In the control group, which was deionized water, a more than $6 \log \mathrm{cfu} / \mathrm{mL}$ inactivation of $V$. parahaemolyticus was achieved within $5 \mathrm{~min}$, while in aquaponics water even after $20 \mathrm{~min}$, the total reduction was $5.2 \log \mathrm{cfu} / \mathrm{mL}$. In addition, the UV-A light-curcumin combination approach reduced 5.5 and $4.1 \mathrm{cfu} / \mathrm{mL}$ of $A$. hydrophila, in deionized water and aquaponics, respectively. Overall, a lower bacterial inactivation was observed in aquaponics water with $6 \mathrm{mg} / \mathrm{L}$ TSS. The efficacy of antimicrobial agent is highly depending on the presence of organic load [7,8]. Organic materials can significantly reduce the antimicrobial activity by reacting with sanitizers, or protecting microorganisms. However, in our study, a more than $4 \log \mathrm{cfu} / \mathrm{mL}$ bacterial reduction was achieved during the photodynamic inactivation using curcumin $(10 \mathrm{mg} / \mathrm{L})$ and UV-A light in real aquaponics model with TSS, suggesting that photodynamic inactivation using curcumin and UV-A light has strong potential for water sanitation in aquaculture and aquaponics systems, and the efficacy of this approach was not significantly influenced by TSS. 

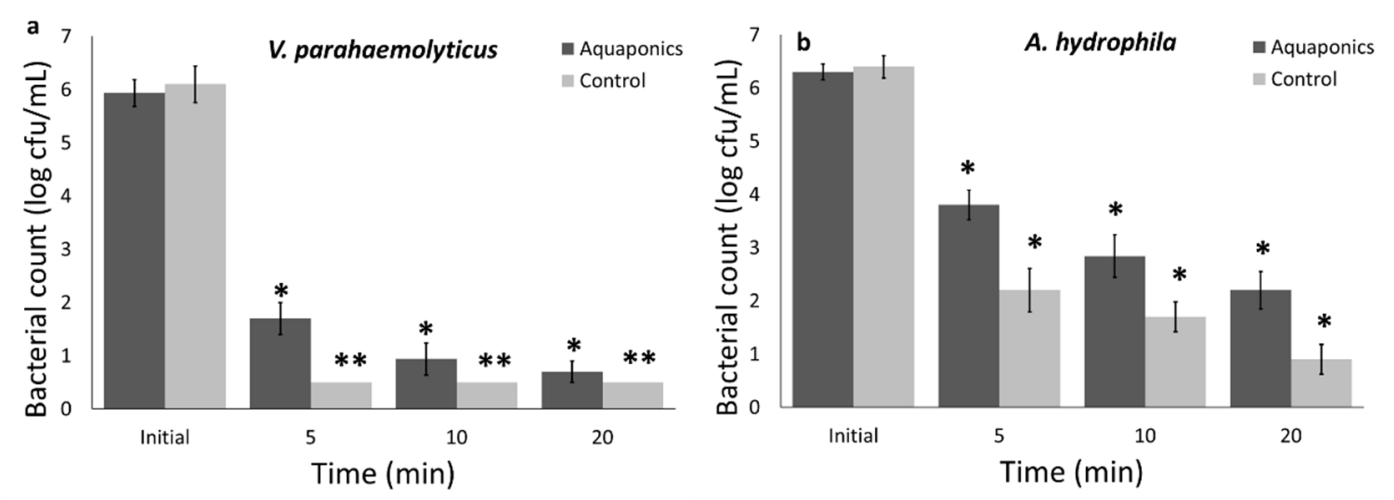

Figure 3. (a) V. parahaemolyticus and (b) A. hydrophila inactivation in PBS and aquaponics water with $6 \mathrm{mg} / \mathrm{L}$ total suspended solid (TSS), using combined UV-A and curcumin antimicrobial approach. Statistical difference was determined based on $p<0.05\left(^{*}\right)$. Samples with two asterisks $\left.{ }^{* *}\right)$ were below the limit of detection $(0.5 \log \mathrm{cfu} / \mathrm{mL})$.

\subsection{Nanobubble and Ultrasound Inactivation}

Figure 4 illustrates the bacterial count in cell suspension after exposure to nanobubbles, ultrasound, and nanobubbles+ultrasound for 5 to $15 \mathrm{~min}$. The results showed that ultrasound and nanobubbles solutions alone cannot significantly reduce bacteria $(p>0.05)$. However, the combination of nanobubbles and ultrasound induced a more than 3 and $6 \log \mathrm{cfu} / \mathrm{mL}$ reduction in V. parahaemolyticus and A. hydrophila, respectively. The results of $V$. parahaemolyticus showed that the bacterial reduction was independent of the exposure time, while more $A$. hydrophila reduction was observed by increasing the exposure time.
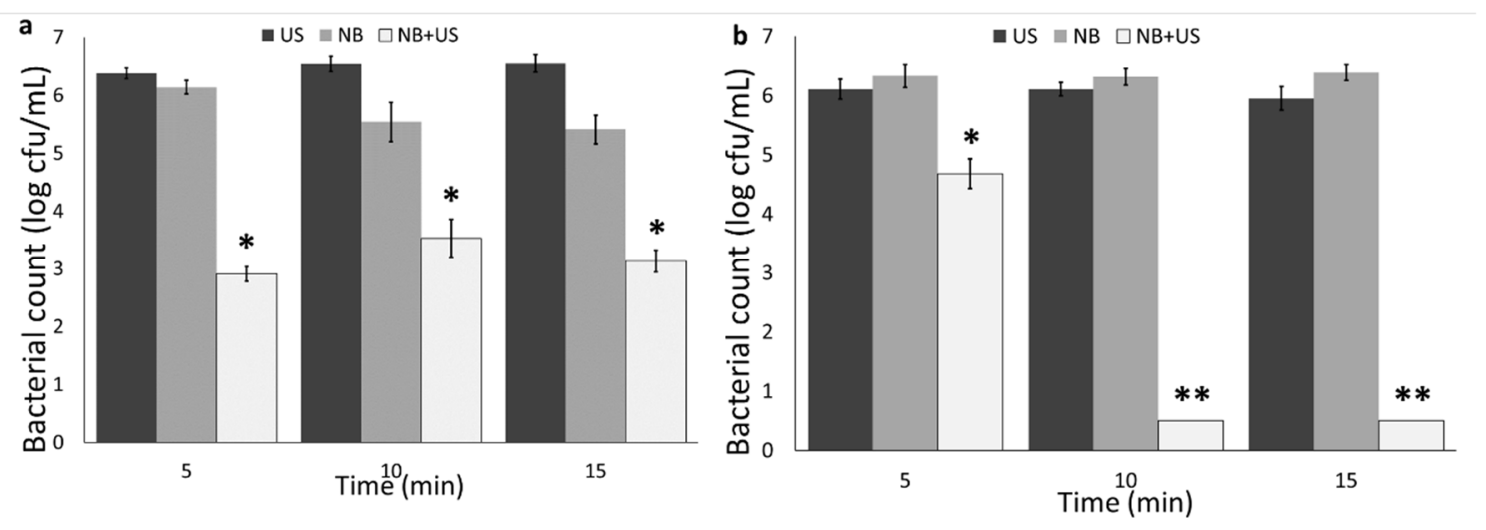

Figure 4. (a) V. parahaemolyticus and (b) A. hydrophila count in nanobubbles (NB), ultrasound (US), and nanobubbles + ultrasound (NB + US) at different exposure times. Statistical difference was determined based on $\left.p<0.05{ }^{*}\right)$. Samples with two asterisks $\left({ }^{* *}\right)$ were below the limit of detection $(0.5 \log \mathrm{cfu} / \mathrm{mL})$.

Ultrasound successfully reduced the bacterial population when it was applied with chemical sanitizers $[34,35]$. Ultrasound alone and in combination with UV-C was applied for inactivating heterotrophic bacteria in intensive aquaculture system which did not result in a significant reduction [36].

Only few studies showed antimicrobial and antibiofilm properties of nanobubbles in combination with chemical sanitizers $[16,17,21,25,26]$. In our previous study, we showed antibiofilm properties on nanobubbles alone and in combination with chemical sanitizers [21].

Antibiofilm and antimicrobial properties of nanobubbles are strongly correlated to the physical properties of the nanobubbles (including high gas transfer capacity), generation of free radicals including $\left(\mathrm{OH}^{\bullet}\right)$, high energy release by bursting and collapsing of bubbles, and the potential generation of reactive oxygen species (ROS) $[21,24,37]$. Due to the high internal pressure in nanobubbles, when they burst on the surface of bacteria because of the ultrasound, they release high surface energy, allowing 
the conversion of $\mathrm{O}_{2}$ to ROS, and cause surface cavitation resulting in bacterial inactivation [18]. Furthermore, hydroxyl radicals can be generated in the water as a result of nanobubble collapse [37]. Hydroxyl radical generation and shock waves from the collapse of small cavities are other possible mechanisms for antimicrobial properties of nanobubbles [16,17]. In our previous study, using Raman spectroscopy, we also showed that nanobubbles cause bacterial DNA degradation, protein oxidation, and cell membrane damage [21].

In an intensive aquaculture system including RAS and aquaponics, appropriate microbial control measures can be achieved via water disinfection using chemical or physical (UV-C) approaches. However, chemical application in RAS and aquaponics systems is limited due to many reasons including: lack of approved therapeutants and chemicals; concerns about compromising fish health, worker health, and environmental safety; chemical residue in fish and plants; risk of impairing microbial communities in biofilters which are oxidizing ammonia, and the functionality of the system strongly depends on them [36,38]. Thus, light-curcumin and nanobubbles-ultrasound combinations could be interesting topics for the fresh produce, aquaculture, and algae mass production systems in the photobioreactors, hydroponics, and aquaponics industries as alternative approaches to treat recycling water. Develop a photo- or nanobubble-reactor may provide a better approach for water treatment in RAS and aquaponics which will solve the permit requirement issues as well.

\section{Conclusions}

UV-A and visible LED in combination with food-grade curcumin can rapidly inactivate aquatic pathogens in water. High bacterial inactivation using curcumin at room and refrigerator temperatures offer a new possible approach for seafood sanitation. Furthermore, by considering the fact that the studied concentrations $(1,5$, and $10 \mathrm{mg} / \mathrm{L})$ are safe for fish [39], and the UV-A and curcumin combination reduced more than $4 \log \mathrm{cfu} / \mathrm{mL}$ of bacteria in aquaponics water, this approach may be applied for real intensive aquaculture, and aquaponics system. Antimicrobial properties of nanobubbles and ultrasound against aquatic pathogens provide a new antimicrobial approach for the first time for water sanitation.

In summary, both light-curcumin and nanobubbles-ultrasound approaches may provide novel alternative sanitation approaches for sensitive systems including aquaculture, aquaponics, hydroponics, algae mass production in reactors, and cell-culture systems.

Author Contributions: S.R.: Methodology, Investigation, Writing-Original Draft. S.S.: Conceptualization, Methodology, Formal Analysis, Investigation, Writing-Original Draft, Writing-Review and Editing. M.H.S.: Conceptualization, Writing-Original Draft and Editing, Project Administration. N.N.: Conceptualization, Methodology, Writing-Original Draft. R.O.: Conceptualization, Methodology, Resources, Data Curation, Writing-Original Draft, Visualization, Supervision, Project Administration, Funding Acquisition. All authors have read and agreed to the published version of the manuscript.

Funding: This research was funded by USDA National Institute of Food and Agriculture, Hatch-1021077.

Acknowledgments: This study was partially supported by the USDA National Institute of Food and Agriculture, Hatch-1021077 and College of Agriculture and Life Sciences at Virginia Tech. We thank David Crosby at Virginia State University for providing the Aeromonas hydrophila strain. We would like to express our sincere thanks to Michael Schwarz, the Director of the Seafood AREC for technical support.

Conflicts of Interest: The authors declare no conflict of interest.

\section{References}

1. Food and Agriculture Organization of the United Nations. Fishery and Aquaculture Statistics. Yearbook. 2019, p. 109. Available online: http://www.fao.org/3/ca5495t/CA5495T.pdf (accessed on 15 September 2020).

2. Kumar, S.; Lekshmi, M.; Parvathi, A.; Nayak, B.B.; Varela, M.F. Antibiotic Resistance in Seafood Borne Pathogens. In Food Borne Pathogens and Antibiotic Resistance; Singh, O.V., Ed.; John Wiley \& Sons: Hoboken, NJ, USA, 2017; pp. 397-416.

3. Vivekanandhan, G.; Hatha, A.A.M.; Lakshmanaperumalsamy, P. Prevalence of Aeromonas hydrophila in fish and prawns from the seafood market of Coimbatore, South India. Food Microb. 2005, 22, 133-137. [CrossRef] 
4. Kledal, P.R.; Thorarinsdottir, R. Aquaponics: A commercial niche for sustainable modern aquaculture. In Sustainable Aquaculture; Hai, F.I., Visvanathan, C., Boopathy, R., Eds.; Springer: Cham, Switzerland, 2018; pp. 173-190.

5. Ovissipour, M.; Rasco, B.; Bledsoe, G.; Shiroodi, S. A Guide to the Aquaponics Food Safety Plan Development: Green Aquaponics LLC as a Model. 2019. Available online: https://vtechworks.lib.vt.edu/bitstream/handle/ 10919/88927/FST-302.pdf?sequence=1 (accessed on 1 June 2020).

6. Oliveira, E.F.; Cossu, A.; Tikekar, R.V.; Nitin, N. Enhanced antimicrobial activity based on a synergistic combination of sublethal levels of stresses induced by UV-A light and organic acids. Appl. Environ. Microbiol. 2017, 83. [CrossRef] [PubMed]

7. Oliveira, E.F.; Tikekar, R.; Nitin, N. Combination of aerosolized curcumin and UV-A light for the inactivation of bacteria on fresh produce surfaces. Food Res. Int. 2018, 114, 133-139. [CrossRef] [PubMed]

8. Oliveira, E.F.; Tosati, J.V.; Tikekar, R.V.; Monteiro, A.R.; Nitin, N. Antimicrobial activity of curcumin in combination with light against Escherichia coli O157: H7 and Listeria innocua: Applications for fresh produce sanitation. Postharvest Biol. Technol. 2018, 137, 86-94. [CrossRef]

9. Liu, F.; Li, Z.; Cao, B.; Wu, J.; Wang, Y.; Xue, Y.; Xu, J.; Xue, C.; Tang, Q.J. The effect of a novel photodynamic activation method mediated by curcumin on oyster shelf life and quality. Food Res. Int. 2016, 87, 204-210. [CrossRef] [PubMed]

10. Penha, C.B.; Bonin, E.; da Silva, A.F.; Hioka, N.; Zanqueta, É.B.; Nakamura, T.U.; Filho, B.A.A.; Campanerut-Sa, P.A.Z.; Mikcha, J.M.G. Photodynamic inactivation of foodborne and food spoilage bacteria by curcumin. LWT-Food Sci. Technol. 2017, 76, 198-202. [CrossRef]

11. Tosati, J.V.; de Oliveira, E.F.; Oliveira, J.V.; Nitin, N.; Monteiro, A.R. Light-activated antimicrobial activity of turmeric residue edible coatings against cross-contamination of Listeria innocua on sausages. Food Control. 2018, 84, 177-185. [CrossRef]

12. Wu, J.; Mou, H.; Xue, C.; Leung, A.W.; Xu, C.; Tang, Q.J. Photodynamic effect of curcumin on Vibrio parahaemolyticus. Photodiagnosis Photodyn. Ther. 2016, 15, 34-39. [CrossRef]

13. Nafisi, S.; Adelzadeh, M.; Norouzi, Z.; Sarbolouki, M.N. Curcumin binding to DNA and RNA. DNA Cell Biol. 2009, 28, 201-208. [CrossRef]

14. Subedi, S.; Du, L.; Prasad, A.; Yadav, B.; Roopesh, M.S. Inactivation of Salmonella and quality changes in wheat flour after pulsed light-emitting diode (LED) treatments. Food Bioprod. Process. 2020, 121, 166-177. [CrossRef]

15. Zhu, J.; An, H.; Alheshibri, M.; Liu, L.; Terpstra, P.M.; Liu, G.; Craig, V.S. Cleaning with bulk nanobubbles. Langmuir 2016, 32, 11203-11211. [CrossRef] [PubMed]

16. Teirlinck, E.; Xiong, R.; Brans, T.; Forier, K.; Fraire, J.; Van Acker, H.; Matthijs, N.; Rycke, R.D.; De Smedt, S.C.; Coenye, T.; et al. Laser-induced vapour nanobubbles improve drug diffusion and efficiency in bacterial biofilms. Nat. Commun. 2018, 9, 1-12. [CrossRef] [PubMed]

17. Teirlinck, E.; Fraire, J.C.; Van Acker, H.; Wille, J.; Swimberghe, R.; Brans, T.; Xiong, R.; Meire, M.; De More, R.J.G.; De Smidt, S.C.; et al. Laser-induced vapor nanobubbles improve diffusion in biofilms of antimicrobial agents for wound care. Biofilm 2019, 1, 100004. [CrossRef]

18. Phan, K.K.T.; Truong, T.; Wang, Y.; Bhandari, B. Nanobubbles: Fundamental characteristics and applications in food processing. Trends Food Sci. Technol. 2019, 95, 118-130. [CrossRef]

19. Shen, Y.; Longo, M.L.; Powell, R.L. Stability and rheological behavior of concentrated monodisperse food emulsifier coated microbubble suspensions. J. Colloid Interface Sci. 2008, 327, 204-210. [CrossRef] [PubMed]

20. Zhu, Z.; Sun, D.W.; Zhang, Z.; Li, Y.; Cheng, L. Effects of micro-nano bubbles on the nucleation and crystal growth of sucrose and maltodextrin solutions during ultrasound-assisted freezing process. LWT 2018, 92, 404-411. [CrossRef]

21. Shiroodi, S.; Schwarz, M.; Nitin, N.; Ovissipour, R. Efficacy of nanobubbles in removing biofilms formed by Escherichia coli O157:H7, Vibrio parahaemolyticus, and Listeria innocua. Food Bioprocess Technol. 2020, under review.

22. Liu, G.; Wu, Z.; Craig, V.S. Cleaning of protein-coated surfaces using nanobubbles: An investigation using a quartz crystal microbalance. J. Phys. Chem. C 2008, 112, 16748-16753. [CrossRef]

23. Wu, Z.; Chen, H.; Dong, Y.; Mao, H.; Sun, J.; Chen, S.; Craig, V.S.J.; Hu, J. Cleaning using nanobubbles: Defouling by electrochemical generation of bubbles. J. Colloid Interface Sci. 2008, 328, 10-14. [CrossRef] 
24. Ghadimkhani, A.; Zhang, W.; Marhaba, T. Ceramic membrane defouling (cleaning) by air Nano Bubbles. Chemosphere 2016, 146, 379-384. [CrossRef]

25. Hayakumo, S.; Arakawa, S.; Takahashi, M.; Kondo, K.; Mano, Y.; Izumi, Y. Effects of ozone nano-bubble water on periodontopathic bacteria and oral cells-in vitro studies. Sci. Technol. Adv. Mater. 2014, 15, 055003. [CrossRef] [PubMed]

26. Ushida, A.; Koyama, T.; Nakamoto, Y.; Narumi, T.; Sato, T.; Hasegawa, T. Antimicrobial effectiveness of ultra-fine ozone-rich bubble mixtures for fresh vegetables using an alternating flow. J. Food Eng. 2017, 206, 48-56. [CrossRef]

27. Kozima, H.; Mukai, Y.; Ransangan, J.; Senoo, S. Feasibility study of applications of micro-bubbles for aquaculture. In Proceedings of the International Conference on Coastal Oceanography and Sustainable Marina Aquaculture, Confluence and Synergy, Sabah, Malaysia, 2-4 May 2006; pp. 220-223. Available online: http://irep.iium.edu.my/11261/ (accessed on 1 June 2020).

28. Roh, H.J.; Kim, A.; Kang, G.S.; Kim, D.H. Photoinactivation of major bacterial pathogens in aquaculture. Fish. Aquat. Sci. 2016, 19. [CrossRef]

29. Kumar, A.; Ghate, V.; Kim, M.J.; Zhou, W.; Khoo, G.H.; Yuk, H.G. Antibacterial efficacy of 405, 460 and 520 $\mathrm{nm}$ light emitting diodes on Lactobacillus plantarum, Staphylococcus aureus and Vibrio parahaemolyticus. J. Appl. Microbiol. 2016, 120, 49-56. [CrossRef]

30. Jori, G.; Fabris, C.; Soncin, M.; Ferro, S.; Coppellotti, O.; Dei, D.; Fantetti, L.; Chiti, G.; Roncucci, G. Photodynamic therapy in the treatment of microbial infections: Basic principles and perspective applications. Lasers Surg. Med. 2006, 38, 468-481. [CrossRef]

31. Ghate, V.S.; Ng, K.S.; Zhou, W.; Yang, H.; Khoo, G.H.; Yoon, W.B.; Yuk, H.G. Antibacterial effect of light emitting diodes of visible wavelengths on selected foodborne pathogens at different illumination temperatures. Int. J. Food Microbiol. 2013, 166, 399-406. [CrossRef]

32. Kussovski, V.; Mantareva, V.; Angelov, I.; Orozova, P.; Wöhrle, D.; Schnurpfeil, G.; Borisova, E.; Avramov, L. Photodynamic inactivation of Aeromonas hydrophila by cationic phthalocyanines with different hydrophobicity. FEMS Microbiol. Lett. 2009, 294, 133-140. [CrossRef]

33. Deng, X.; Tang, S.; Wu, Q.; Tian, J.; Riley, W.W.; Chen, Z. Inactivation of Vibrio parahaemolyticus by antimicrobial photodynamic technology using methylene blue. J. Sci. Food Agric. 2016, 96, 1601-1608. [CrossRef]

34. Ajlouni, S.; Sibrani, H.; Premier, R.; Tomkins, B. Ultrasonication and fresh produce (Cos lettuce) preservation. J. Food Sci. 2006, 71, 62-68. [CrossRef]

35. Huang, K.; Wrenn, S.; Tikekar, R.; Nitin, N. Efficacy of decontamination and a reduced risk of cross-contamination during ultrasound-assisted washing of fresh produce. J. Food Eng. 2018, 224, 95-104. [CrossRef]

36. Lakeh, A.A.B.; Kloas, W.; Jung, R.; Ariav, R.A.; Knopf, K. Low frequency ultrasound and UV-C for elimination of pathogens in recirculating aquaculture systems. Ultrason. Sonochem. 2013, 20, 1211-1216. [CrossRef]

37. Demangeat, J.L. Gas nanobubbles and aqueous nanostructures: The crucial role of dynamization. Homeopathy 2015, 104, 101-115. [CrossRef]

38. Pedersen, L.-F.; Pedersen, P.B. Hydrogen peroxide application to a commercial recirculating aquaculture system. Aqua. Eng. 2012, 46, 40-46. [CrossRef]

39. Liu, Y.M.; Zhang, Q.Z.; Xu, D.H.; Fu, Y.W.; Lin, D.J.; Zhou, S.Y.; Li, J.P. Antiparasitic efficacy of curcumin from Curcuma longa against Ichthyophthirius multifiliis in grass carp. Vet. Parasitol. 2017, 236, 128-136. [CrossRef]

(C) 2020 by the authors. Licensee MDPI, Basel, Switzerland. This article is an open access article distributed under the terms and conditions of the Creative Commons Attribution (CC BY) license (http://creativecommons.org/licenses/by/4.0/). 